\title{
Self efficacy and Organizational Commitment of IT employees in Coimbatore District
}

\author{
*Dr.N.Nirmala Devi, "Sinduja.R \\ "Principal, "Ph.D Research Scholar, ${ }^{*}$ "Dr.G.R.Damodaran Academy of Management, India \\ "nimaji.grdam@gmail.com, ${ }^{\#}$ prabhusinduja@gmail.com
}

Abstract: The current study is conducted on self-efficacy and organisational commitment of IT Employees in Coimbatore District. The objective of the study is to find the relationship between Self-efficacy and Organisational Commitment of IT Employees. A Sample of 100 employees including males and females, working in IT industry in Coimbatore District were selected. The employees were given the structured questionnaire, designed and tested by Schwarzer, R., \& Jerusalem, M. (1995), Pethe et al. (1999), Allen, N. and Meyer, J. (1990). ANOVA test was used to find the difference between the variables and Pearson Correlation test was used to calculate the relationship between the variables. The results revealed that there was no significant association between male and female and self-efficacy and organisational commitment, and there was significant relationship between self-efficacy and organisational commitment and thus the research accepted the alternate hypothesis.

Keywords: IT Employees, Organisational commitment, Self-efficacy

\section{INTRODUCTION}

Self-efficacy is defined "as the belief in one's ability to execute successfully, a certain course of behaviour" (Bandura, 1986). Efficacy beliefs affect self- motivation and action through their impact on goals and aspirations. It's partly on the idea of efficacy beliefs that folks pick what goal defies to undertake, what quantity of effort to devote within the effort, and the way long to continue in the face of worries (Bandura, 1997 ; Locke and Latham,1990 ). The studies on self-efficacy by Albert Bandura are a pioneer in self-efficacy researches. Consistent to Bandura (1986), self-efficacy impacts the work related behaviours and employee performance. Organisational commitment measures have been found to have impact on employee motivation (Blau, 1988). A satisfied employee is a great asset to the organisation, while the turnover intention and attrition are the major problem of the organisations today. Low self-efficacy stimulates negative feelings about one's abilities and responsibility for one's own performance. A high degree of self-efficacy stimulates the perception that one is accountable for one's destiny and that one can do what one wants to do. Many small to mid-size manufacturing companies have become progressively aware of how an actual human resource leader can contribute to the success of the industry's bottom line. With the continuous growth in the IT industry, the role of HR is bound to play an even more

Organizational commitment could also be a psychological state that binds the individual to organization during which they work (Allen \& Mayer, 1991). Researchers identified three kinds of commitment: affective commitment is that the emotional attachment, identification, and involvement of employees with organization and goals (Mowday et al., 1997; \& Meyer \& Allen, 1993); continuance commitment is that the willingness to stay in a corporation (Reichers, 1985); and normative commitment is that the feeling of person's obligation to organization (Bolon, 1993). Pertinent literature suggests certain individual attributes as significant predictors of organizational commitment. For instance, Luthans and Youssef (2007) found that organizational commitment is positively related with hope, optimism, and resilience (Luthans \& Youssef, 2007) whereas Hurter (2008) and Sinha, Talwar, and Rajpal (2002) found self-efficacy as positive correlate of organizational commitment.

The present study has been done to study the relationship between self-efficacy and organisational commitment of employees. The three component model proposed by Allen and Meyer (1990) was used to study the organisational commitment of employees. The respondents of the study were the middle level employees of IT industry in Coimbatore. With Coimbatore, being a hub of IT and ITES industries, this study would serve those sector with the need of improving the self efficacy of its employees.

\section{LITERATURE REVIEW}

Liu and et al (2019) conducted a study on relationship between self-efficacy and organisational commitment. It was found from their study that self-efficacy had a positive relationship on organisational commitment. Chi square test and structural equation modelling were used to test the 
data. The respondents of the study were part-time MBA students in China. They also argued that self-efficacy had a direct effect on organisational commitment and indirect effect on work engagement.

BA Mokoena and et al (2019) explored the relationship between self-efficacy, job satisfaction and organisational commitment of sport coaches in South Africa. Confirmatory factor analysis and structural path modelling were the tools to assess the relationship between the constructs. The results of the study showed significant positive relationship between self-efficacy, job satisfaction and organizational commitment.

Shalini Srivastava and Prachi Patak (2019) purpose of the study was to explore the self-efficacy, organisational commitment and job involvement on job performance among private bank employees of Uttarakhand and Uttar Pradesh. Exploratory factor analysis and multiple regression analysis were used in the study. It was also revealed that self-efficacy had a significant impact on job performance and organisational commitment had insignificant impact on job performance.

Onyeizugbe and et al (2018), according to this study selfefficacy of employees enhances the organisational commitment of employees in South East Nigeria. Survey type of design was used in the study. The results of their study revealed a positive significant relationship between self-efficacy and organisational commitment of brewing employees.

Prudhomme and et al(2018) research aimed toward exploring the connection between vocational self-efficacy and employee relationship during career transition. General model of commitment proposed be Meyer (2010) was utilized in the study. it had been argued within the study that every component of Organisational commitment had a positive and significant relationship with self-efficacy.

S K Moon (2018) purpose of the study was to seek out the connection between self-efficacy, emotional labor, organisational commitment and job satisfaction of medical tourism employees. SPSS 12.0 and AMOS 18.0 was accustomed to test the info . It had been found that self efficacy positively influenced on job satisfaction and organisational commitment of employees.

Albrecht and Amrty (2017) examined the extent to which the personality characteristics influenced the employee's psychological connection to their work. It was found from their study that personality characteristics were positively associated with self-efficacy and affective commitment. Structural equation modelling was used to test the data collected.

Cem Sen and et al (2017) in their study explored the effects of organisational psychological capital on Organisational commitment. Correlation and regression analysis were used to test the data. The respondents were the employees of government organisation of Turkey. The research showed a positive relationship between psychological capital and organisational commitment.

Ata Pesan (2016) studied whether there was significant difference between self-efficacy and expectation levels for the future among High school students. Kruskal Wallis test and Mann-Whitney $U$ test were applied in the study. The research findings demonstrated that the self-efficacy level of students in high school do not change with gender and class. Further, there was a significant difference between self-efficacy of the students and age and income status.

Fang Mei Law and et al (2015) in their study explored the correlation of hope and self-efficacy with job satisfaction and organisational commitment. Regression analysis was used to test the data. The respondents of the study were correlational officers in Taiwan prison system. The results of the study publicised a positive and significant association self-efficacy with organisational commitment.

\section{RESEARCH METHODOLOGY}

\section{Research questions:}

1. Do self-efficacy and organisational commitment have a significant relationship?

2. Does gender significantly differ on self-efficacy among IT Employees in Coimbatore?

3. Does gender significantly differ on organisational commitment among IT Employees in Coimbatore?

4. Does self-efficacy predict the organisational commitment of IT employees?

\section{Objectives:}

1. To study the relationship between self-efficacy and organisational commitment of IT employees in Coimbatore.

2. To study the significant difference between selfefficacy among Male and female employees of IT industry.

3. To study the significant difference between organisational commitment among Male and female employees of IT industry.

4. To study the influence of self-efficacy on organisational commitment of IT employees.

\section{Hypothesis}

$\mathrm{H}_{1} \mathrm{O}$ : There is no significant relationship between selfefficacy and Organisational commitment of IT employees in Coimbatore.

$\mathrm{H}_{2} 0$ : Male and Female employees do not differ significantly on self-efficacy.

$\mathrm{H}_{3} \mathrm{O}$ : Male and Female employees do not differ significantly on organisational commitment. 
$\mathrm{H}_{4} 0$ : There is no significant influence of self-efficacy on organisational commitment of IT employees.

\section{Variables:}

Self-efficacy (General self-efficacy and self-efficacy)

Organisational Commitment

\section{Research Design:}

The research study is descriptive method and a total of 100 respondents were considered. The sampling technique used was stratified sampling. The sample contained 100 employees including males and females belonging to IT industry in Coimbatore District.

\section{Sources of Data:}

Primary data: The primary data was collected through structured questionnaire and interview method.
Secondary data: secondary data was collected from websites, journals and magazines.

\section{Sampling unit:}

IT Employees of Coimbatore District.

\section{Scales used:}

General self-efficacy scale by Schwarzer, R., \& Jerusalem, M. (1995) and Self-efficacy scale by Pethe et al. (1999).

Organisational Commitment Scale by Allen, N. and Meyer, J. (1990).

\section{Tools used:}

The following tools were used to analyse the data Pearson Correlation

ANOVA

Regression analysis

\section{ANALYSIS AND INTERPRETATION}

The data analysis primarily involved Correlation to find the whether there was statistically significant relationship between Self-efficacy and Organisational Commitment of the respondents.

Table 1: Relationship between Self-efficacy and Organisational Commitment of the respondents-Correlation.

\begin{tabular}{|ll|r|r|}
\hline \multicolumn{1}{|c|}{ Correlations } & SE & OC \\
\hline SE & Pearson Correlation & 1 & \\
& Sig. (2-tailed) & $.620^{* *}$ \\
& $\mathrm{~N}$ & .004 \\
& Pearson Correlation & 100 & 100 \\
\hline OC & Sig. (2-tailed) & $.620^{* *}$ & \\
& $\mathrm{~N}$ & .004 & 1 \\
& & 100 & 100 \\
\hline
\end{tabular}

**. Correlation is significant at the 0.01 level (2-tailed).

The above table 1, shows the relationship between Self-efficacy and Organisational Commitment of IT Employees. Since the $\mathrm{r}$ value is .620, it shows a positive and significant correlation between the variables, hence the null hypothesis, $\mathrm{H}_{1} 0$ is rejected and alternative hypothesis, $\mathrm{H}_{1} 1$ is accepted. From the table, it is interpreted that there is significant relationship between Selfefficacy and Organisational Commitment of the respondents $(r=.620, p=.004)$,

Table 2: Significant difference between self-efficacy of male and female IT employees.-ANOVA

ANOVA

SE

\begin{tabular}{|l|r|r|r|r|}
\hline & Sum of Squares & df & Mean Square & F \\
\hline Between Groups & .008 & 1 & .008 & .215 \\
Within Groups & 3.871 & 98 & .039 \\
Total & 3.880 & 99 & .846 \\
& & \\
& & & \\
\end{tabular}

The above table 2, shows that there is no significant difference between Self-efficacy of male and female IT employees $(\mathrm{f}=.039, \mathrm{p}=.846)$. Since the $\mathrm{p}$ value is. 846 , which is more than .05 , the null hypothesis, $\mathrm{H}_{2} 0$ is agreed, that states there is no significant difference between self-efficacy of male and female IT employees and the alternative hypothesis is disagreed.

Table 3: Significant difference between organisational commitment of male and female IT employees.-ANOVA

ANOVA

\begin{tabular}{|c|c|c|c|c|c|}
\hline & Sum of Squares & $\mathrm{df}$ & Mean Square & $\mathrm{F}$ & Sig. \\
\hline Between Groups & 1.582 & 1 & 1.582 & 3.862 & .065 \\
\hline Within Groups & 7.374 & 98 & .410 & & \\
\hline Total & 8.956 & 99 & & & \\
\hline
\end{tabular}


The above table 3, shows that there is no significant difference between Organisational Commitment of male and female IT employees $(\mathrm{f}=3.862, \mathrm{p}=.065)$. Since the $\mathrm{p}$ value is.065, which is more than .05 , the null hypothesis, $\mathrm{H}_{3} 0$ is agreed, that states there is no significant difference between organisational commitment of male and female IT employees and the alternate hypothesis is disagreed.

Table 4: Significant influence of self-efficacy on organisational commitment-Regression.

\begin{tabular}{|c|c|c|c|c|c|c|}
\hline \multicolumn{7}{|c|}{ ANOVA $^{a}$} \\
\hline & & Sum of Squares & df & Mean Square & $\mathrm{F}$ & Sig. \\
\hline \multirow{3}{*}{1} & Regression & 3.447 & 1 & \multirow{3}{*}{$\begin{array}{r}3.447 \\
.306\end{array}$} & \multirow[t]{3}{*}{11.261} & \multirow{3}{*}{$.004^{\mathrm{b}}$} \\
\hline & Residual & 5.509 & 98 & & & \\
\hline & Total & 8.956 & 99 & & & \\
\hline
\end{tabular}

a. Dependent Variable: OC1

b. Predictors: (Constant), SE

The table 4, reports the regression results for organisation commitment being predicted by self-efficacy. It is observed that $(\mathrm{f}=11.261, \mathrm{p}=.004)$, since the $\mathrm{p}$ value is .004 , which is less than .05 , the result support the alternate hypothesis, $\mathrm{H}_{4} 1$. Hence the alternative hypothesis is agreed, that states the independent variable, self-efficacy reliably predict the dependent variable, organisational commitment.

\section{FINDINGS}

Correlation Analysis of the study showed a positive and significant relationship between Self Efficacy and Organisational Commitment of the respondents. The results revealed that the $\mathrm{r}$ value is .620 , where the alternative hypothesis, stating there is positive correlation between self-efficacy and organisational commitment of IT employees. This finding is supported by few studies as follows, Miss Saman Zeb etal (2016) "Impacts of SelfEfficacy on Organizational Commitment of Academicians A Case of Gomal University", Dr. Hamed Saremi (2015) "A Study on the Relationship between Self-Efficacy Beliefs and Organizational Commitment with Job Satisfaction in Office Employees in Esfarayen City, Iran”.

ANOVA results of the study that found that there is no significant difference between self-efficacy of male and female respondents. It was also found from the study that there is no significant difference between Organisational Commitment of male and female respondents. This finding is in alignment with the following study by M.Singer(1991) "The relationship between employee sex, length of service and leadership aspirations: A study from valence, self-efficacy and attribution perspectives",

\section{REGRESSION ANALYSIS}

The regression analysis showed that the, self-efficacy reliably predicts the organisational commitment of IT employees. It is also found that self-efficacy has significant influence on organisational commitment of IT employees. The results are consistent with the studies of Bogler and Somech's study (2004), which states that self-efficacy as a predictor of organisational commitment.

\section{SUGGESTIONS}

- The Self-efficacy of the employees can be improved by conducting personality development courses, hence their performance will enable the organisation to achieve its goal.

- If employees have good knowledge, skills and ability related to their work, it would increase their confidence and efficiency in performing their work.

- Employees with high self confidence and skills, when recognised by giving promotions, it may lead to enrichment of organisational commitment.

- Employees with high level of self efficacy when selected during the interview may be more effective in their performance. The increased organisational commitment of employees leads to satisfaction towards their job, which in turn reduces the turn over intention.

- Various studies of Bandura, prove that self-efficacy enhances the work performance of employees. Hence, the selection process, while hiring can be based on assessing the self-efficacy of the candidates to assure their performance, which might turn a greater advantage and strength of the organisation.

- The current study also reveals that the self-efficacy of employees, predict the organisational commitment. Thus the self-efficacious employees stay committed to the organisation, who serve as the competitive advantage of the organisation, may also continue their career with great aspiration towards the firm, regardless of the existence of competitor organisations.

\section{CONCLUSION}

The findings of the study suggest that, the organisations need to improve the self-efficacy of employees, which may 
serve as a tool for retaining the employees. The results of the study revealed a positive and significant correlation between Self-efficacy and Organisational Commitment, $(\mathrm{r}=.625, \mathrm{p}=.004)$. The results were consistent with the previous literature, which shows that Self Efficacy is predictor of organisational commitment of employees. (Saba Ghayas \& Adnan Adil, 2012). There are no adequate review on the self-efficacy of employees working in the IT sector, specifically in India. In this regards, the researcher has reviewed the outcomes of related literature. The influence of self-efficacy on motivation and flexibility have not been discussed in this study. The main aim of the study is to study the relationship between and the influence of the self-efficacy on organisational commitment.

\section{REFERENCE}

[1.] Liu, E. (2019). Occupational self-efficacy, organizational commitment, and work engagement. Social Behavior and Personality: an international journal, 47(8), 1-7.

[2.] Mokoena, B. A., \& Dhurup, M. (2019). Self-Efficacy, Organisational Commitment, Job Satisfaction and Satisfaction With Life Relationships: a Study Among Amateur Sport Coaches in South Africa. International Journal of Social Sciences and Humanity Studies, 11(1), 19-34.

[3.] Srivastava, S., \& Pathak, P. (2019). Impact of SelfEfficacy, Organizational Commitment and Job Involvement on Job Performance in Private Bank Employees. In Proceedings of 10th International Conference on Digital Strategies for Organizational Success.

[4.] Onyeizugbe, C. U., Orogbu, O. L., \& Chinwuko, O. B. (2018). Self-Efficacy and Employee Commitment in Selected Breweries in South East Nigeria. Business Management and Strategy, 9(1), 1-17.

[5.] Prudhomme, N., Loarer, E., \& Lallemand, N. (2018). Vocational self-efficacy and organizational commitment during career transitions. Le travail humain, 81(1), 61-84.

[6.] Moon, S. K. (2018). The Relationship among Self Efficacy, Emotional Labor, Organizational Commitment and Job Satisfaction of Medical Tourism Employees. Korea Journal of Hospital Management, 23(3), 39-51.

[7.] Albrecht, S. L., \& Marty, A. (2017). Personality, selfefficacy and job resources and their associations with employee engagement, affective commitment and turnover intentions. The International Journal of Human Resource Management, 1-25.

[8.] ŞEN, C., Mert, I. S., \& AYDIN, O. (2017). The Effects Of Positive Psychological Capital On Employee's Job
Satisfaction, Organizational Commitment, And Ability Coping With Stress. Journal of Academic Research in Economics, 9(2).

[9.] Ata Pessen (2016). A Research on Self Efficacy and Future expectations of Students in Vocational High Schools. Turkish Online Journal of Education Technology (2016:34-43),

[10.] Law, F. M., \& Guo, G. J. (2016). Correlation of hope and self-efficacy with job satisfaction, job stress, and organizational commitment for correctional officers in the Taiwan prison system. International journal of offender therapy and comparative criminology, 60(11), 1257-1277.

[11.] Ghayas, Saba (2012). Self-efficacy and optimism as predictors of organizational commitment among bank employees. https://doi.org/10.5861/ijrsp.2012.131.

[12.] Ghafoor, A., Qureshi, T. M., Azeemi, H. R., \& Hijazi, S. T. (2011). Mediating role of creative selfefficacy.

African Journal of Business Management, 5, 1109311103 .

[13.] Bogler, R., \& Somech, A. (2004). Influence of teacher empowerment on teachers' organizational commitment,

professional commitment and organizational citizenship behavior in schools. Journal of Teaching and

Teacher Education, 20, 277-289.

[14.] Bandura, A. (2004). Cultivate self-efficacy for personal and organizational effectiveness. In E. A. Locke (Ed.), Handbook of principles of organizational behavior (pp. 120-136). Malden, MA: Blackwell.

[15.] Singer, M. (1991). The relationship between employee sex, length of service and leadership aspirations: A study from valence, self-efficacy and attribution perspectives. Applied Psychology, 40(4), 417-436.

[16.] Bandura, A. (1977). Self efficacy: Toward a unifying theory of behavioral change. Psychological Review,

84 , 191-215. 